\title{
LEGAL PROTECTION ON CHILDREN AS A VICTIMS OF SEXUAL VIOLENCE BASED ON PROGRESSIVE LAW
}

\author{
Etik Purwaningsih \\ Pengadilan Negeri Jepara \\ etikpurwaningsih22@gmail.com
}

\begin{abstract}
Sexual violence happened to children are often occurred, after the emergence of sexual cases in Jakarta International School (JIS). It began to arise attention to child victims of sexual violence. This paper aims to provide a review of the protection on child victims of sexual violence at this time. With the sociological juridical method, the primary data were obtained from direct interviews with law enforcement officers, while secondary data were obtained from literature references. The result shows that the legal protection does not pay attention on children as victim. The legal protection for children as victim sexual violence is expected to give punishment to the criminals in the form of payment of compensation to the victim whose amount is determined in the court, or fulfillment of the obligation of the Local custom or legal obligations that live in society or social and mental rehabilitation. If the convicted person tries to avoid giving the compensation, the convicted person is not entitled to a reduction in the criminal term and does not get conditional released.
\end{abstract}

Keywords: Legal protection, children as victim, sexual violence, progressive.

\section{A. Introduction}

Since the New Order era, the problem of national stability including law enforcement has become a major component of the development. One of the elements in the trilogy of development is the desire to realize the national development effort "the creation of national stability is safe and dynamic". However, until the reform era today the work is never finished. Sahetapy states that the problem of crime is always an interesting issue, both before and after criminology experiencing growth 
and development as it is today ${ }^{1}$. From one side of this understanding seems unjust and does not show empathy to the victim of the crime.

Increasingly human and technology is in line with the variety and pattern of crimes. Not only in Indonesia, basically every developed society and society in modern age has an interest in controlling crime and reducing crime rates through various alternative law enforcement ${ }^{2}$. According to ArifGosita, one of the backgrounds of this victimology is "integrated widespread observation". According to him, everything must be observed in a broadly integrated (macro-integral) manner next to the micro-clinical observation, if we want to get a reality picture of the actual proportion dimensionally about something, especially about the relevance of something. ${ }^{3}$

Child sexual abuse is a form of child abuse in which older adults or adolescents use children for sexual stimulation. Forms of child sexual abuse include soliciting or suppressing a child for sexual activity (regardless of outcome), providing obscene exposure of the genitals to the child, featuring pornography for children, engaging in sexual intercourse with children, physical contact with the child's genitals (Except in certain non-sexual contexts such as medical examinations), looking at the child's genitals without physical contact (except in a non-sexual context such as a medical examination), or using a child to produce child pornography. ${ }^{4}$

Nowadays the mass media is brightened by news about the existence of sexual violence against child. Types of sexual abuse experienced by children most often occur in the form of sodomy, rape,

\footnotetext{
${ }^{1}$ J.E. Sahetapy, 2006, Teori Kriminologi Suatu Pengantar, Citra AdityaBakti, Bandung, page 31.

${ }^{2}$ Ninik Widiyanti dan Panji Anoraga, 2007, Perkembangan Kejahatan dan Masalahnya, Pradnya Paramita, Jakarta, page 58

${ }^{3}$ Arief Gosita, Victimologi dan KUHAP, Akademika Pressindo, Jakarta 2006, page 8

${ }^{4}$ Sexual Harassment to Children, www.wikipedia.com is accessed on November 3, 2014 
obscenity and incest. Cases of sexual assault against children occur almost in all regions of Indonesia. The latest case in South Jakarta (DKI Jakarta), the case of sexual violence that occurred at the JIS (Jakarta International School) in the period February-March 2014 has opened our eyes to all how the mental damage of the young generation today.

The fine penalty stated in both the Child Protection Act does not need to be applied, because the penalty does not accommodate the interest of the child as the victim of sexual crime. Criminal penalty is actually only accommodate the interests of the state, namely as income to the state treasury which it does not provide any benefit for children as victims of sexual crimes. Axiological, the protection of the victim (including children) of crime (violence) may include forms of abstract protection (indirect) as well as concrete (direct). Abstract protection is basically a form of protection that can only be enjoyed or felt emotionally (psychically), such as satisfaction. Meanwhile, concrete protection is essentially a form of protection that can be enjoyed in a real way, such as in the form of a material or non-material nature. Material granting may be in the form of compensation or restitution, exemption of living expenses or education. The granting of non-material protections may be exempt from threats, from degrading reports of human dignity.

Child protection not only covers the protection of their rights, but also related to the aspect of youth development ${ }^{5}$, In Law Number 23 Year 2004 on Child Protection jonto Law Number 35 Year 2014 About Amendment To Law Number 23 Year 2004 About Child Protection jo Government Regulation in Lieu of Law No. 1 of 2016 Concerning Second Amendment to Law Number 23 Year 2004 on Child Protection states that for perpetrators of sexual violence crime, they shall be punished with

${ }^{5}$ Aminah Aziz, 1998, Aspek Hukum Perlindungan Anak, USU Press, Medan, page 26 
imprisonment and fine penalty. It is also provided with additional criminal in the form of identity announcement of the perpetrator, and the installation of electronic detective equipment. The imprisonment is intended for the perpetrators to deter the offender from repeating his actions, while the fine is paid to the state. From the three laws, the protection for child victims of sexual crime is not accommodated. Child victims of sexual crimes who suffer from the actions of the perpetrators of their interests are not noticed. The judge as a case breaker has no other option to impose penalties for the perpetrator except for imprisonment and a fine penalty. The judge can only provide compensation for the child of the victim of a sexual crime if the child as a victim of a sexual crime filed a claim for damages. On the other hand, the additional criminal is not binding for IPR. In practice, the judge may impose additional criminal as well as no bias.

Actually, the fine penalty contained in the Child Protection Act does not need to be included in the Child Protection Act. Something that should be included in the Child Protection Act is something that can accommodate the interests of children as victims of sexual crimes, namely the imposition of restitution without any claim/demand from children as victims of sexual crimes. In addition, there is also a need for legal renewal of the criminal type both of the principal and additional criminal sanction contained in Law Number 23 Year 2004 jonto Law Number 35 Year 2014 jonto Government Substitute Law Number 1 Year 2016 About Second Amendment To Law Number 23 Year 2002 on Child Protection.

The granting of protection to child victims of sexual crimes, especially in the form of compensation, either through compensation and/or restitution, should receive the attention of policy makers. 
Regarding compensation and restitution, Stephen Schafer ${ }^{6}$, in his book "The Victim and His Criminal", proposes 5 (five) systems of giving compensation and restitution to victims of crime, namely: (1) civil damages, provided through civil law process, separate With criminal proceedings; (2) civic compensation, provided through a criminal process; (3) restitution which is civil and mixed with criminal nature, given through criminal process; (4) civilian compensation, provided through criminal proceedings and backed by sources of state income; (5) Neutral compensation is provided through special procedures. The purpose of the study is To examine the legal protection for children as victims of sexual violence under current positive law. Besides that this study also aims to examine the weaknesses of legal protection for children in the crime of sexual violence against children today.

This paper used empirical juridical approach based on field research, it was also used to obtain primary data, whilestudy literature was used to obtain secondary data. Empirical law studies are studies in the form of empirical studies to find out theories about the process of legal work in society.

\section{B. Research Results and Discussion}

\section{Legal Protection for Children as Victims of Sexual Violence}

According to $\mathrm{Mu}^{\prime} \mathrm{anah}^{7}$, as the Public Prosecutor at the Jepara Prosecutor's Office, it was found that the general description of the crime of sexual violence against children as victims was often regarded as sexual immorality, rape or coercion (the entry of male genitalia into the vagina)

${ }^{6}$ Stephen Schafer, 2008, The Victim and His Criminal, Randam House, New York, page 105

${ }^{7}$ Interview with Mu'anah, as the Public Prosecutor at the Jepara Prosecutor's Office, on September 8, 2015 
perpetrated by the perpetrator and as the object or the victim are children who often get undue behavior due to certain causes such as: persuasion and seduction to offer something to the victim. The physical side as children is often much weaker than adults. Thus, the perpetrator engages in a coercion/sexual violence against a child imaginable by several factors such as social misconduct, environmental factors, depression, psychological disorders, lack of education and insight and supervision of Level of parents, family to related government, social media, print and electronic media that has been growing and easy to find or obtain such as photos / pictures, video recordings and others.

According to MujiSantoso ${ }^{8}$, as Head of the Child Protection Subdivision of the Women's Empowerment and Family Planning Agency of Jepara District, the general description of the crime of sexual violence against children as victims is a form of child abuse who are under 18 (eighteen) years old, in which older adults or adolescents uses children for sexual stimulation. Forms of child sexual abuse include soliciting or suppressing a child for sexual activity (regardless of outcome), providing obscene exposure of the genitals to the child, featuring pornography for children, engaging in sexual intercourse with children, physical contact with the child's genitals, Looking at the child's genitals without physical contact or using children to produce child pornography, rape and having sex on the basis of likes and exploits of children who are prostitutes.

Based on the results of interviews with Suranto ${ }^{9}$, as Chairman of the Jepara District Court, I obtained information that the crime of sexual violence against children as victims includes asrising criminal acts. It is because of the development of existing violent sexual violence of late has

\footnotetext{
${ }^{8}$ Interview with MujiSantoso, as Head of Child Protection Sub-division of Women's Empowerment and Family Planning Agency of Jepara Regency, on August 10, 2015 ${ }^{9}$ Interview with Suranto, as Chairman of Jepara District Court, on 5 August 2015 
experienced a significant increase andJepararaised as second popular in Central Java.

According to Mu'anah ${ }^{10}$, as the Public Prosecutor at the Jepara Prosecutor's Office, the case of the crime of sexual violence against children as victims is a prominent crime because the child is the future of the nation that should be protected. Furthermore, in Jepara the sexual violence against children as victims is very much. Meanwhile, according to Rukin $^{11}$, as the Public Prosecutor at the Jepara Prosecutor's Office, that in Jepara District the criminal acts of violence against children including prominent criminal acts because based on data from the Child Empowerment Division in PemdaJepara and from SuaraMerdeka's Newspaper source we obtained data that the problem Violence against children in Jepara was ranked first in Central Java.

Based on the results of the interview with RennySofyani ${ }^{12}$, as the Public Prosecutor at the Jepara Prosecutor's Office, obtained information that law enforcement against the perpetrators of violence against children of course we as the Public Prosecutor provide the criminal as provided for in the new Child Protection Act and we In demanding conformity with the act of the defendant itself and from the facts in the trial, for example for sexual violence against children committed by violence or the threat of violence of course criminal prosecution is higher than sexual violence committed by deceit, a series of lies, or with persuasion And because of the minimal threat of high then we think it is enough to provide a deterrent effect against the perpetrators.

\footnotetext{
${ }^{10}$ Interview with Mu'anah, as the Public Prosecutor at the Jepara Prosecutor's Office, on September 8, 2015

${ }^{11}$ Interview with Rukin, as the Public Prosecutor at the Jepara Prosecutor's Office, on September 9, 2015

${ }^{12}$ Interview with Renny Sofyani as Public Prosecutor at State Prosecutor of Jepara, on September 10, 2015
} 
According to Hastopo ${ }^{13}$, as Vice Chairman of Jepara District Court, Handling of criminal cases of sexual violence is not included as a matter of priority handling. The court has not made a case of a crime of sexual violence as a priority or preferable case.

Based on the interview with Rukin ${ }^{14}$, as the Public Prosecutor at the Jepara Prosecutor's Office, it is found that the modus operandi of the criminal act of sexual violence in Jepara Regency is usually the criminal firstly go date with the victim, then given the lure usually in the form of money, mobile phone or other materials even with invited to go to a place, then persuaded so that the victim eventually be raped by the perpetrator. Another mode is if the perpetrator is the family of the victim, he usually by leverage about the cost of life of the victim borne by the perpetrator so that the victim feels indebted and uncomfortable to refuse to make a love with the perpetrator.

According to RennySofyani ${ }^{15}$, as the Public Prosecutor at the Jepara Prosecutor's Office, the Child Protection Act must have accommodated special protection for children as regulated in Article 59 paragraph (1) of Law Number 35 Year 2014 on Child Protection which reads Governments, local governments and other state institutions have the obligation and responsibility to provide special protection for children, but in practice the local government is not concerned with the condition of the victim because in the trial according to the victim's own information there is no protection from any institution against the victims of sexual violence . Likewise as Article 69A, in which this article specifically provides protection

\footnotetext{
${ }^{13}$ Interview with Hastopo, as Vice Chairman of Jepara District Court, on August 4, 2015

${ }^{14}$ Interview with Rukin, as the Public Prosecutor at the Jepara Prosecutor's Office, on September 9, 2015

${ }^{15}$ Interview with Renny Sofyani, as Public Prosecutor at Jepara Prosecutor Office, on September 10, 2015 
to child victims of sexual crimes, as referred to in Article 59 is done through the efforts of:

a. Education on reproductive health, religious values and moral values

b. Social rehabilitation

C. Psychosocial assistance during treatment until recovery

d. Provide protection and assistance at every level of examination from investigation, prosecution to trial in court.

Recent developments in criminal law indicate that the principle of law is no longer rigidly or rigidly determined, but the principle of law has been retained as a fundamental principle in criminal law even with various modifications and development. ${ }^{16}$

Based on the results of the interview with RennySofyani ${ }^{17}$, as the Public Prosecutor at the Jepara Prosecutor's Office, the researcher obtained information that because there is no legal protection against the victim of course has not fulfilled the sense of justice for victims of sexual violence. Meanwhile, according to Mu'anah ${ }^{18}$, as the Public Prosecutor at the Jepara Prosecutor's Office, the legal protection of the child as a temporary victim is enough to fulfill the sense of justice when it is associated with the development of law in Indonesia.

According to MujiSantoso ${ }^{19}$, as Head of Child Protection Subdivision of Women's Empowerment and Family Planning Agency of Jepara Regency, the legal protection for children as victims of sexual violence according to the positive law is now in accordance with the need to

\footnotetext{
${ }^{16}$ Barda Nawawi Arief, 1996, Bunga Rampai Kebijakan Hukum Pidana, Citra AdityaBakti , Bandung, page 88

${ }^{17}$ Interview with RennySofyani, as Public Prosecutor at Jepara Prosecutor Office, on September 10, 2015

${ }^{18}$ Interview with Mu'anah, as the Public Prosecutor at the Jepara Prosecutor's Office, on September 8, 2015

${ }^{19}$ Interview with MujiSantoso, as Head of Child Protection Sub-division of Women's Empowerment and Family Planning Agency of Jepara Regency, on August 10, 2015
} 
protect children as victims of the sexual violence contained in the articles Which is contained in the contents of the child protection legislation, but the supporting element has not been maximized, due to the lack of fulfillment of facilities and infrastructure.

According to AiptuRofiqah ${ }^{20}$, as the Kanit PPA PolresJepara, law enforcement against the crime of sexual violence against children conducted by the Police Jepara is guided by Law No. 11 of 2012 on the Criminal Justice System of Children by prioritizing efforts for the settlement in kinship that is intended to impact To the psychological child as a victim, if the case must be settled to the hearing. Regarding the legal protection of children as victims of sexual violence, according to AiptuRofiqah ${ }^{21}$, asKanit PPA PolresJepara, is in accordance with the need to protect children as victims of sexual violence contained in the articles contained in the contents of child protection legislation, But the supporting element has not been maximized due to the lack of fulfillment of facilities and infrastructure. Legal protection of children as victims already fulfills a sense of justice, because of mutual consent which is more concerned with moral settlement than is legally positive. For the legal protection of children as victims of sexual violence has not been implemented properly, because of the lack of assistance to children as victims of sexual violence, both material and psychological.

According to Andi Rio $\mathrm{P}^{22}$, as a Member of the House of Representative of the Republic of Indonesia, Law No. 34 of 2014 on Amendment to Law Number 23 Year 2002 on Child Protection is intended to complement and improve the provisions contained in Law Number 23

\footnotetext{
${ }^{20}$ Interview with AiptuRofiqah, as Head of PPA PolresJepara, on 12 August 2015

${ }^{21}$ Interview with AiptuRofiqah, as Head of PPA PolresJepara, on 12 August 2015

${ }^{22}$ Interview with Andi Rio P., as Member of the House of Representatives of the Republic of Indonesia, on 14 August 2015
} 
Year 2002 such as restitution. Law Number 34 Year 2014 on Amendment to Law Number 23 Year 2002 regarding Child Protection has provided legal protection to victims.

Based on the results of interviews with Ubaidillah ${ }^{23}$, from the Ministry of Social Affairs of the Republic of Indonesia, obtained information that in the Ministry of Social Affairs to accompany victims of violence accompanied by Social Workers (Peksos). In handling of victims in the Ministry of Social is divided into two parts, namely victims/children who get legal protection and children/victims who need special protection. For assistance to victims there is PSAA under the Ministry of Social Affairs all made as LPSK. By 2014 social worker homes are already integrated. The function of Child Social Protection House (RPSA) is to rehabilitate victims but not necessarily in the area.

According to RetnoAdjiPrasetiaju ${ }^{24}$, as the Commissioner of the Indonesian Child Protection Committee (KPAI), for the protection of victims of sexual violence the government has noticed the victims through rehabilitation to the community even to the reintegration done by the Ministry of Social Affairs, the budget already exists but the implementation is not maximized.

\section{Legal Protection Against Children as Victims of Progressive Sexual Violence Victim}

Legal protection for children as victims of sexual violence related to criminal offenses against perpetrators has not been effective and has not provided protection to victims. Therefore, based on the analysis, it needs to be renewed on the protection of children as victims of sexual violence

\footnotetext{
${ }^{23}$ Interview with Ubaidillah, from the Ministry of Social Affairs of the Republic of Indonesia, on August 24, 2015

${ }^{24}$ Interview with RetnoAdjiPrasetiaju, as Commissioner of Indonesian Child Protection Commission (KPAI), on August 25, 2015
} 
by basing on the new theory that the researcher found. The theory of legal protection of children victims of sexual violence based on the effectiveness of the law. Reconstruction of legal protection law for children as victims of progressive legal-based sexual violence can be done through 2 (two) ways namely reconstruction of values and legal reconstruction:

a. Renewal of values, namely strengthening the legal protection of children victims of sexual violence through the strengthening of basic criminal punishment in the form of compensation to victims for material loss costs, social rehabilitation of victims and mental rehabilitation of victims, strengthening religious education for children, strengthening moral education and the introduction of the dangers of crime Early childhood sexual, strengthening of human resource potential, and establishment of child protection institution victim of sexual violence.

b. Legal renewal is the reconstruction of Articles 81 and 82 of Law Number 35 Year 2014 on Amendment to Law Number 23 Year 2002 regarding Child Protection jo Government Regulation in Lieu of Law Number 1 Year 2016 About Second Amendment to Law Number 23 Year 2002 About Child Protection needs to be reconstructed with a progressive legal mindset or theory.

So that Article 81 and 82 of Law Number 35 Year 2014 concerning Amendment to Law Number 23 Year 2002 regarding Child Protection jo Government Regulation in Lieu of Law Number 1 Year 2016 About Second Amendment of Law Number 23 Year 2002 About Child Protection From the results of the renewal can answer as well as provide a sense of justice to children as victims of criminal acts and provide legal certainty for the community, especially children. 
The right of restitution for victims as regulated in Law Number 35 Year 2014 regarding the Amendment of Law Number 23 Year 2002 on Child Protection has not been able to fulfill the sense of justice for children as victims of sexual violence. The provision of restitution and compensation aims to restore the losses suffered by the victims both physically and psychologically, as well as reimbursement for the costs incurred as a result of victimization.

Legal protection for child victims of sexual violence, strengthening legal protection of child victims of sexual violence through strengthening of basic criminal punishment in the form of compensation to victims for material loss cost, social rehabilitation of victims and mental rehabilitation of victims, strengthening religious education for children, strengthening moral education and introduction The danger of early child sexual crimes, the strengthening of human resource potential and the establishment of child protection institutions for victims of sexual violence.

Legal protection for child victims of sexual violence in the future, it is expected that the perpetrator is also sentenced in the form of compensation payment to the victim, the amount determined in the decision or fulfillment of local custom obligation or obligation according to law living in society or social and mental rehabilitation. If the convicted person tries to avoid compensation for compensation to the victim, the convicted person is not entitled to a reduction in the criminal term and does not get parole. The perpetrator is castrated (sentenced to death) if the child is a victim of a sexual assault of 2 (two) children or more.

\section{Conclusion}

Based on the above descriptions it can be concluded that the legal protection for children as victims of sexual violence in the Child Protection Act is only to regulate the unlawful acts of the perpetrators viewed from 
the usnur and the threat of criminal article which is quite high and coupled with the fine, Which is certainly enough to make the perpetrators of sexual violence will be deterrent, but the Child Protection Act does not fully provide legal protection for children as victims. Special protection for children is provided in Article 59 paragraph (1) of Law Number 35 Year 2014 on Child Protection which reads as government, regional government and other state institutions have responsibility and responsibility to give special protection to children, but in practice local government not concerned on the condition of the victim.

Children as victims of sexual violence in the implementation of their legal protection have been implemented fairly well, but it is better for each region established Witness Protection Institution or an institution or team or container whose duty is to carry out socialization, monitoring, monitoring, counselingwith law enforcement officers, who pick up the ball. Victims' protection has been largely abstract or indirect protection means that the formulation of criminal offenses in legislation has meant that there has been in fact indirect protection against the various interests of the law and the rights of victims. While renewal in the legal protection of children as victims of progressive legal-based criminal violence in the criminal law system in Indonesia in the future so that in the law other than mentioned legal protection against the victim in any form should also mentioned any institution authorized to Provide legal protection to the victim because it is very important because the victims of course need protection of their personal self.

Renewal in the legal protection of children as victims of progressive legal-based sexual violence based on legal protection theory of child victims of sexual violence based on effectiveness is done through 2 (two) things: 
1. The renewal of values in the form of strengthening the legal protection of child victims of sexual violence through the strengthening of basic criminal punishment in the form of compensation to the victims for material loss costs, social rehabilitation of victims and mental rehabilitation of victims, strengthening religious education for children, strengthening moral education and introduction of danger acts Early child sexual crimes, strengthening of human resource potential and the establishment of child protection institutions victims of sexual violence.

2. Legal reform in the form of legal renewal of Articles 81 and 82 of Law Number 35 Year 2014 concerning Amendment to Law Number 23 Year 2002 regarding Child Protection and legal renewal of articles 81 and 82 of Government Regulation in Lieu of Law No. 1 of 2016 on Amendment Second on Law Number 23 Year 2002 on Child Protection with a progressive mindset or legal theory.

Legal protection for child victims of sexual violence in the future, it is expected that the perpetrator is also sentenced in the form of compensation payment to the victim, the amount determined in the decision or fulfillment of local custom obligation or obligation according to law living in society or social and mental rehabilitation. If the convicted person tries to avoid compensation for compensation to the victim, the convicted person is not entitled to a reduction in the criminal term and does not get parole. The perpetrator is castrated (sentenced to death) if the child is a victim of a sexual assault of 2 (two) children or more. 


\section{References}

Aminah Aziz, 1998, Aspek Hukum Perlindungan Anak, USU Press, Medan Arief Gosita, Victimologi dan KUHAP, Akademika Pressindo, Jakarta 2006 Barda Nawawi Arief, 1996, Bunga Rampai Kebijakan Hukum Pidana, Citra AdityaBakti , Bandung

Interview with Mu'anah, as the Public Prosecutor at the Jepara Prosecutor's Office, on September 8, 2015

Interview with Mu'anah, as the Public Prosecutor at the Jepara Prosecutor's Office, on Interview with MujiSantoso, as Head of Child Protection Sub-division of Women's Empowerment and Family Planning Agency of Jepara Regency, on August 10, 2015

Interview with Retno Adji Prasetiaju, as Commissioner of Indonesian Child Protection Commission (KPAI), on August 25, 2015

Interview with Rukin, as the Public Prosecutor at the Jepara Prosecutor's Office, on September 9, 2015

Interview with Suranto, as Chairman of Jepara District Court, on 5 August 2015 September 8, 2015

Interview with Ubaidillah, from the Ministry of Social Affairs of the Republic of Indonesia, on August 24, 2015

J.E. Sahetapy, 2006, Teori Kriminologi Suatu Pengantar, Citra AdityaBakti, Bandung

Ninik Widiyanti dan Panji Anoraga, 2007, Perkembangan Kejahatan dan Masalahnya, Pradnya Paramita, Jakarta

Sexual Harassment to Children, www.wikipedia.com is accessed on November 3, 2014

Stephen Schafer, 2008, The Victim and His Criminal, Randam House, New York 